Нуреев Р.М. Экономические санкции против России и российские антисанкции: издержки и выгоды конфронтации

УДК 338.14

DOI: $10.21779 / 2500-1930-2017-32-3-94-102$

\title{
P.M. Hуреeв
}

\section{Экономические санкции против России и российские антисанкции: издержки и выгоды конфронтации ${ }^{1}$}

Финансовый университет при Правительстве РФ; Россия, 125468, г. Москва, пр. Ленинградский,49; nureev50@gmail.com

Основная цель статьи - определение издержек и выгод экономических санкций, введенных США и Евросоюзом против России, и российских антисанкций. Они были введены против российских компаний, функционирующих в нефтяной и газовой отраслях, финансовой и банковской сферах, оборонно-промышленном комплексе. В ответ на экономические санкции Россия ввела эмбарго, которое выразилось в запрете на ввоз мяса, рыбы, молочной продукции на территорию Российской Федерации.

Даны оценки, во сколько обошлись для Запада и какой урон нанесли России санкции, с одной стороны, и российские антисанкции, с другой.

Рассматриваются два возможных варианта ближайшего развития событий с точки зрения рядового потребителя: пессимистичный и оптимистичный. Основаниями для пессимистического прогноза являются дальнейшее усиление экономических санкций и продолжение падения цен на нефть. В этом случае произойдет углубление экономической изоляции России от мирового сообщества

Предпосылками для оптимистического прогноза развития являются рост цен на нефть и ослабление экономических санкций. Это приведет к укреплению российского рубля, что создаст большие возможности для увеличения импорта, поскольку сделает его более дешевым

Ключевые слова: западные экономические санкции, российские антисанкиии, анализ «издержки-выгодыл».

Прошло три года, как США и их союзники ввели экономические санкции против России. Они были направлены против российских компаний, функционирующих в нефтяной и газовой отраслях, финансовой и банковской сферах, обороннопромышленном комплексе. В ответ на экономические санкции Россия ввела эмбарго, которое выразилось в запрете на ввоз мяса, рыбы, молочной продукции на территорию Российской Федерации. Разберем, достигли ли экономические санкции и антисанкции своих целей. Если достигли, то в какой степени, а если нет, то почему?

\section{1. Экономические санкции против России: анализ выгод и издержек}

Введение экономических санкций против России в области нефтяной и газовой промышленности было подготовлено предшествующим периодом развития экономики США.

\footnotetext{
${ }^{1}$ Статья подготовлена по материалам доклада, представленного на III Международной научнопрактической конференции «Модернизация экономических систем: опыт и перспективы», которая прошла 27-28 апреля 2017 года в Дагестанском государственном университете (г. Махачкала, РФ).
} 
Нуреев Р.М. Экономические санкции против России и российские антисанкции: издержки и выгоды конфронтации

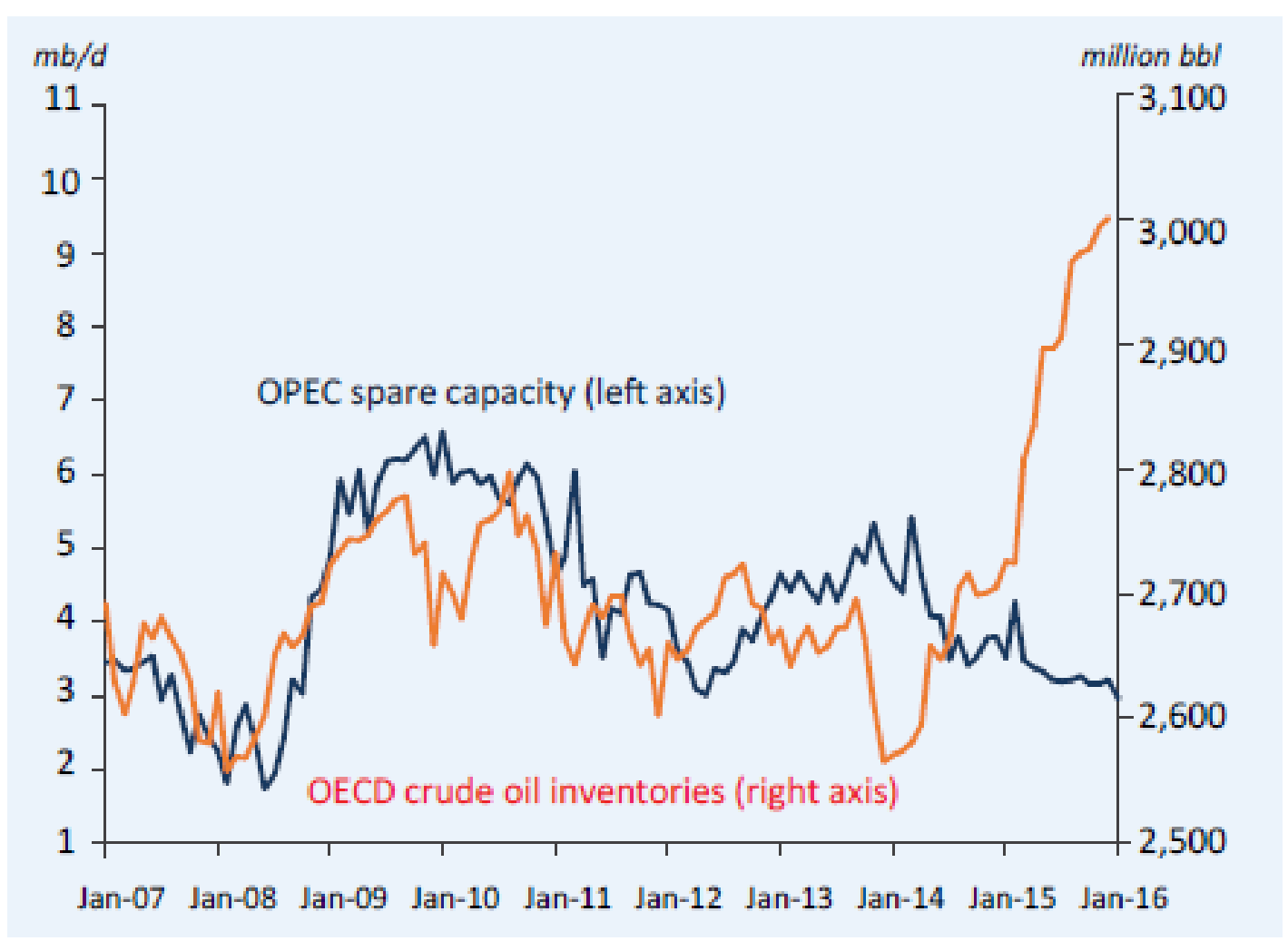

Рис. 1. Избыточный глобальный объем производства нефти и ее запасы [5, с. 29]

После длительного падения производства нефти в США, начавшегося в 1970-е гг. и продолжавшегося вплоть до 2008 г., начался его резкий рост (www.eia.gov). Это привело не только к удовлетворению внутренних потребностей, но и к экспорту нефтяных продуктов из США, который начался после 2005 г. Что же касается производства природного газа в США, то здесь ситуация также значительно улучшилась после 2005 г. (www.eia.gov). Фактически в 2008 г. был превышен максимум 1980 года.

Для усиления своего конкурентного преимущества Соединенные Штаты вводят запрет на экспорт в Россию технологий по нефтедобыче и нефтепереработке, а также замораживают уже существующие и отказываются от заключения новых проектов в газовой отрасли. Это, по мысли авторов санкций, приведет к замедлению роста нефтяной и газовой промышленности в России и в конечном итоге к их техническому отставанию. Действительно, последствия экономических санкций для России не замедлили сказаться. У Роснефти под вопросом оказалась перспектива добычи в Арктике.

Чистая прибыль Роснефти упала в первом квартале 2015 года по сравнению с первым кварталом 2014 г. на 36 \% (с 88 до 56 млрд руб.). Газпром начал искать новых поставщиков оборудования для работ на шельфе. ЛУКОЙЛ сократил инвестиционную программу на 2015 на \$2 млрд, потому что чистая прибыль Лукойла в 2014 г. по сравнению с 2013 сократилась на треть. 
Нуреев Р.М. Экономические санкции против России и российские антисанкции: издержки и выгоды конфронтации

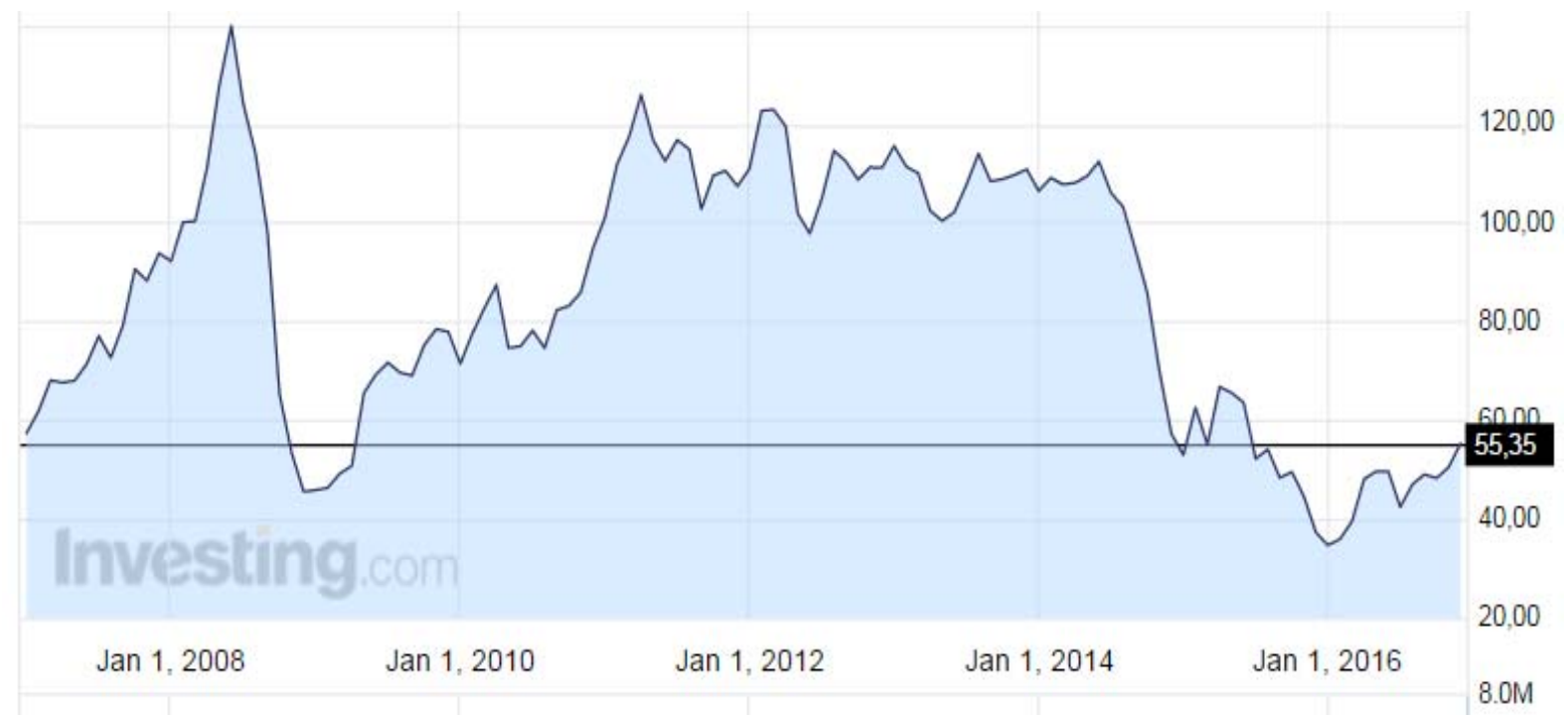

Рис. 2. Динамика цен на нефть с 1 декабря 2006 по 1 ноября 2016 гг.

[http://ru.investing.com/commodities/brent-oil]

В результате наращивания производства сырой нефти Соединенными Штатами и другими странами OECD возникает ее избыточный глобальный объем (рис. 1), который способствует снижению мировых цен на энергоносители. В результате расширения мирового предложения нефти, динамика цен на нефть имела тенденцию к падению, которое приобрело лавинообразный характер в июне 2014 г. (рис. 2). И хотя ситуация во второй половине 2016 года стала немного улучшаться, уровень цен лишь слегка превышает кризисный минимум 2008-2009 годов.

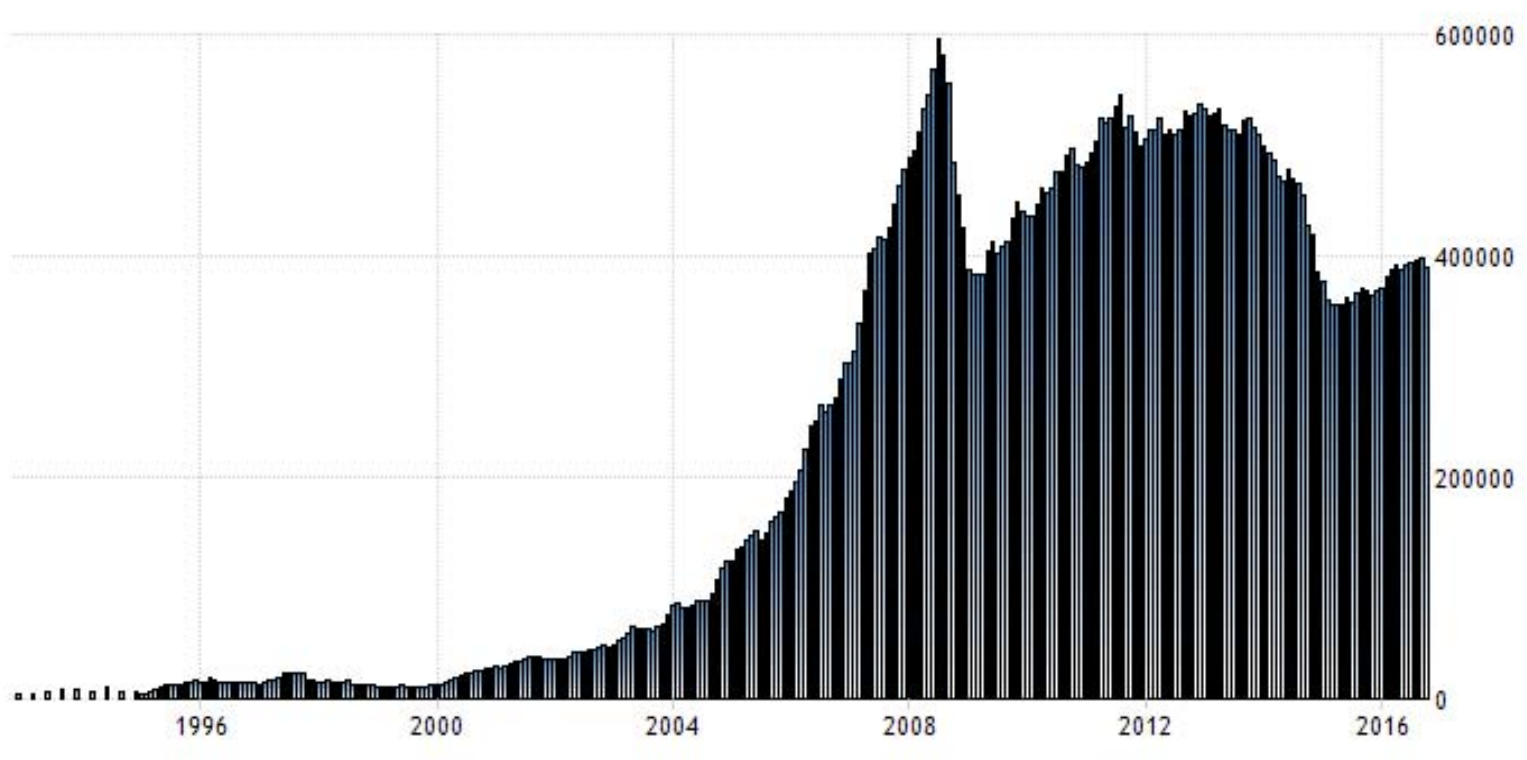

Рис. 3. Международные резервы России с 2011 по 2016 (в млн дол)

[http://ru.tradingeconomics.com/russia/foreign-exchange-reserves]

Важным каналом воздействия экономических санкций запада стало значительное ухудшение доступа к рынкам капитала, что проявилось в резком падении чистого при- 
Нуреев Р.М. Экономические санкции против России и российские антисанкции: издержки и выгоды конфронтации

тока зарубежных прямых инвестиций. Начавшееся еще в 2013 году, оно продолжилось и в 2014. Это привело к тому, что прямые инвестиции в Россию стали поступать из офшоров - с Кипра, Багамских островов, Бермудских островов и т. д.

В результате в 2014 г. резко снизились международные золото-валютные резервы России. Особенно сильное снижение начинается с августа 2014 г. (рис. 3). Так, к началу 2015 г. международные резервы сократились на 24,6 \% по сравнению с началом 2014 года, при этом снижение на $19.1 \%$ произошло как раз в период с августа 2014 по январь 2015 г. В итоге, если на 01.02.2014 международные резервы РФ составляли 498,9 млрд дол., то на 12.12.2016 этот показатель находился на уровне 385,3 млрд дол.

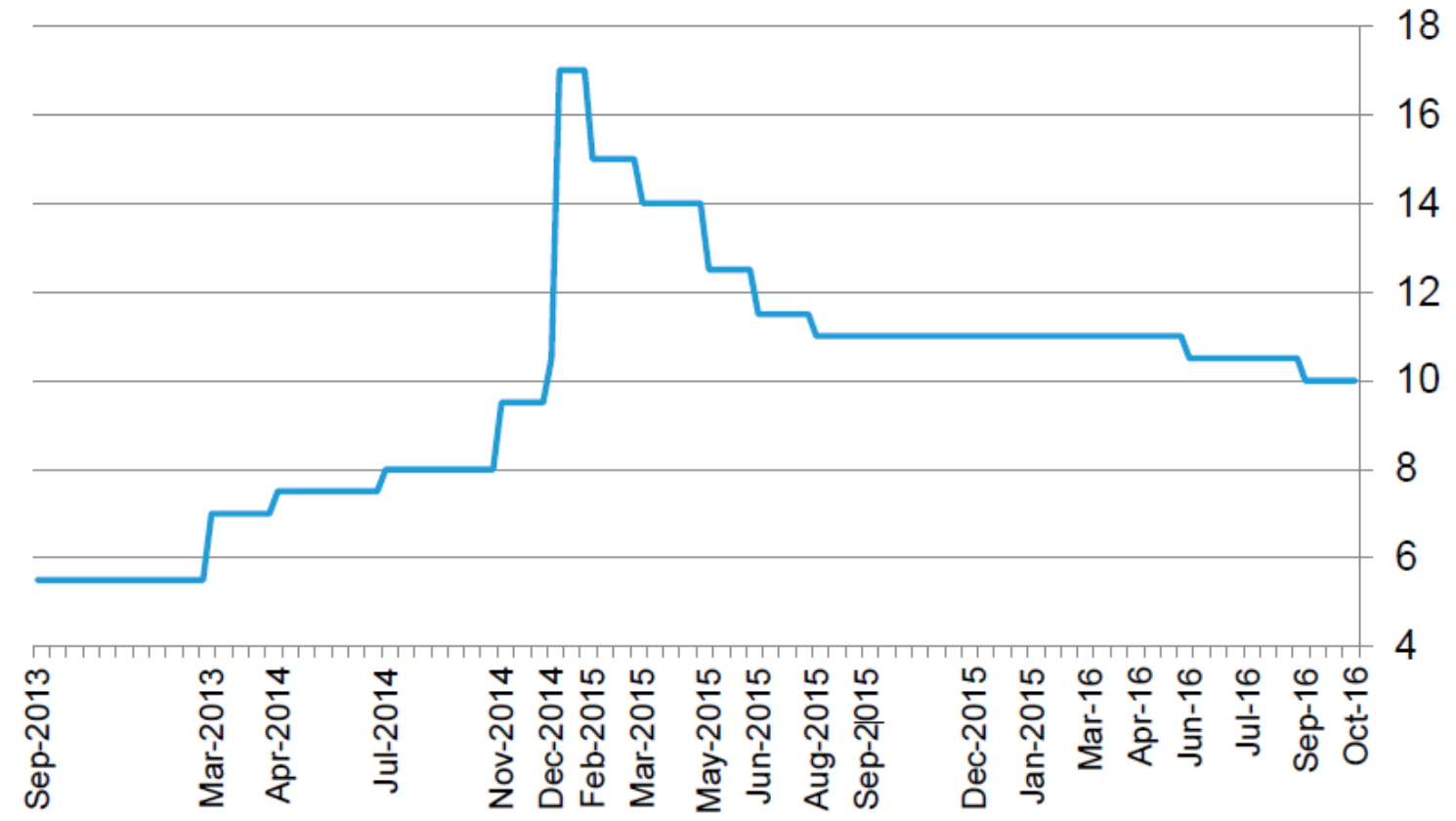

Рис. 4 Ключевая процентная ставка в \% [6, с. 20]

Суть экономических санкций заключалась в том, что российским банкам и компаниям запретили брать кредиты на срок более 30 дней, что вкупе с уменьшением потока долларов от импорта нефти привело к резкому дефициту национальной валюты, что в свою очередь повлекло за собой рост курса доллара и падение курса рубля. Центральный Банк, для того чтобы бороться с волатильностью трижды в 4 квартале 2014 года повышал ключевую ставку, что привело к сильному подорожанию кредитов. Самым большим ударом по банковской системе стало увеличение ключевой ставки с 10,5 до $17 \%$ 16.12.2014 [3]. Таким образом, ключевая ставка в 2014 году выросла с 5,5\% до $17 \%$ (рис. 4).

Подорожание кредитов ударило по потребителям: 1) банкротства предприятий и увеличившаяся кредитная нагрузка привели к росту безработицы; 2) произошло удорожание потребительских, ипотечных, автокредитов и т. д.; 3) ослабление рубля привело к резкому подорожанию валюты и, следовательно, импортных товаров. Эти меры Центрального Банка не ослабили, а, наоборот, объективно усилили эффективность экономических санкций Запада. В результате, по оценкам экспертов МВФ, санкции против РФ стоили экономике России 1-1,5 \% немедленного роста ВВП, а кумулятивные потери от них могут достичь $9 \%$ роста [1]. 
В сентябре 2015 года главный экономист Citigroup по России и СНГ Иван Чакаров в аналитическом докладе о российской экономике раскритиковал распространённое на Западе мнение о том, что санкции оказали существенное влияние на российский ВВП, и благодаря статистическому анализу связал с санкциями 0,4 \% падения ВВП из 4,4 \% полного падения с пика ко второму кварталу 2015 года, остальные 4 \% объяснив падением цен на нефть [http://www.rbc.ru/finances/28/09/2015/560949839a7947b23fa7cd0c]

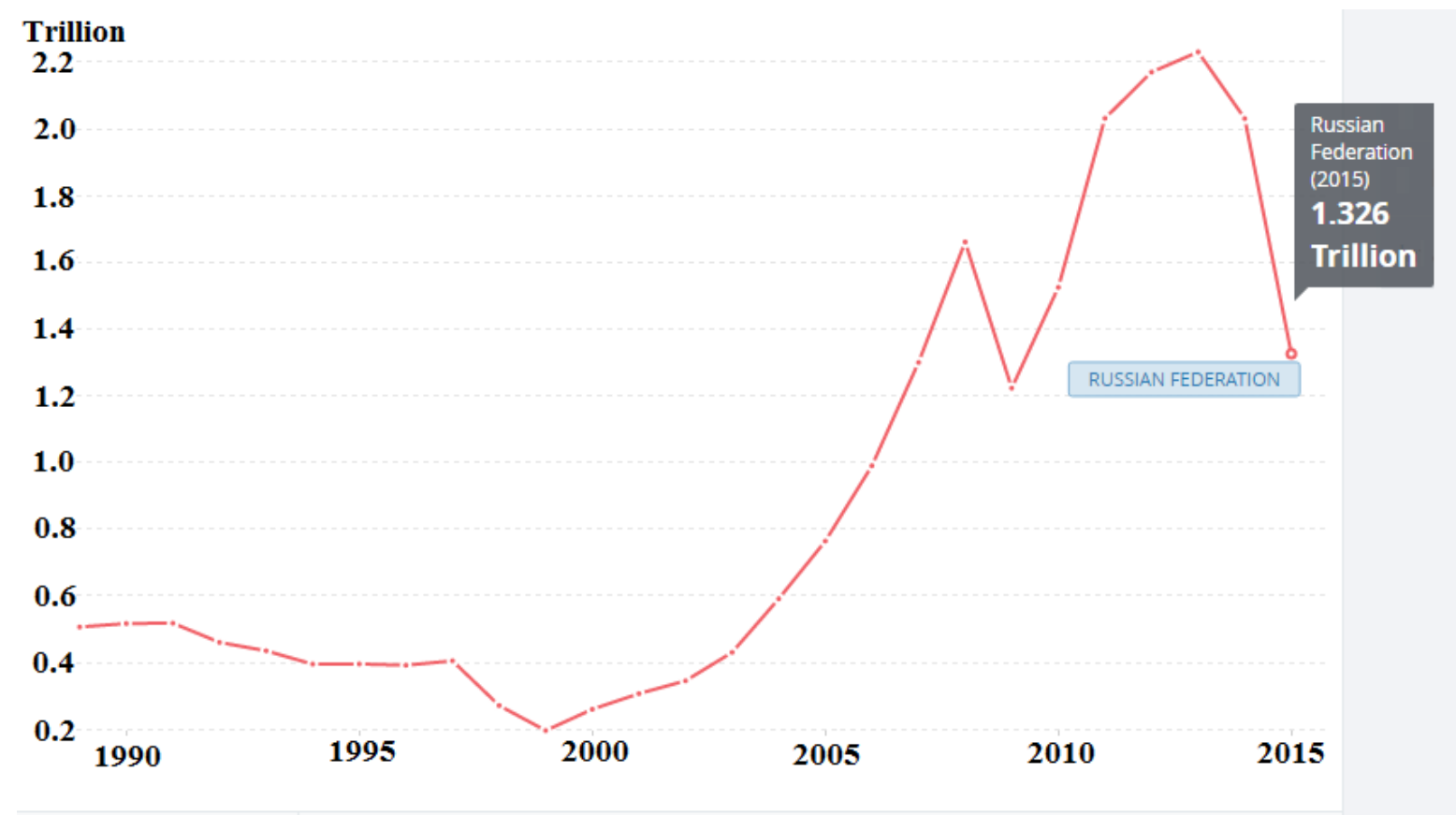

Рис. 5. Валовый внутренний продукт РФ с 1990 по 2015 гг.

[http://data.worldbank.org/indicator/NY.GDP.MKTP.CD?end=2015\&locations=RU\&start=1989\&vie $\mathrm{w}=$ chart $]$

Хотя падение удалось замедлить в 3-м квартале 2015 г., однако до сих пор темпы роста экономики находятся в отрицательной зоне. Расчеты Всемирного Банка показывают, что в 2017 г. темпы роста ВВП России достигнут 1,1 \%, а в 2018 г. - 1,8 \% (см. табл. 1). Однако это заметно ниже темпов роста высокоразвитых стран, которые составят $2,1 \%$, глобального роста ВВП $(3,1 \%)$ и значительно ниже темпов роста развивающихся стран (5,3\%).

Таблица 1. Глобальный рост ВВП, в \%

\begin{tabular}{|c|c|c|c|c|c|c|c|c|c|c|}
\hline & 2009 & 2010 & 2011 & 2012 & 2013 & 2014 & $2015 e$ & $2016 f$ & $2017 f$ & $2018 f$ \\
\hline World & -1.8 & 4.3 & 3.1 & 2.4 & 2.4 & 2.6 & 2.4 & 2.9 & 3.1 & 3.1 \\
\hline High income & -3.5 & 3 & 1.9 & 1.4 & 1.2 & 1.7 & 1.6 & 2.1 & 2.1 & 2.1 \\
\hline $\begin{array}{l}\text { Developing coun- } \\
\text { tries }\end{array}$ & 3 & 7.8 & 6.3 & 4.9 & 5.3 & 4.9 & 4.2 & 4.8 & 5.3 & 5.3 \\
\hline Euro area & -4.5 & 2 & 1.7 & -0.7 & -0.2 & 0.9 & 1.5 & 1.7 & 1.7 & 1.6 \\
\hline Russia & -7.8 & 4.5 & 4.3 & 3.5 & 1.3 & 0.7 & -3.7 & -1.9 & 1.1 & 1.8 \\
\hline
\end{tabular}

Источник: [5, с. 27] 
Нуреев Р.М. Экономические санкции против России и российские антисанкции: издержки и выгоды конфронтации

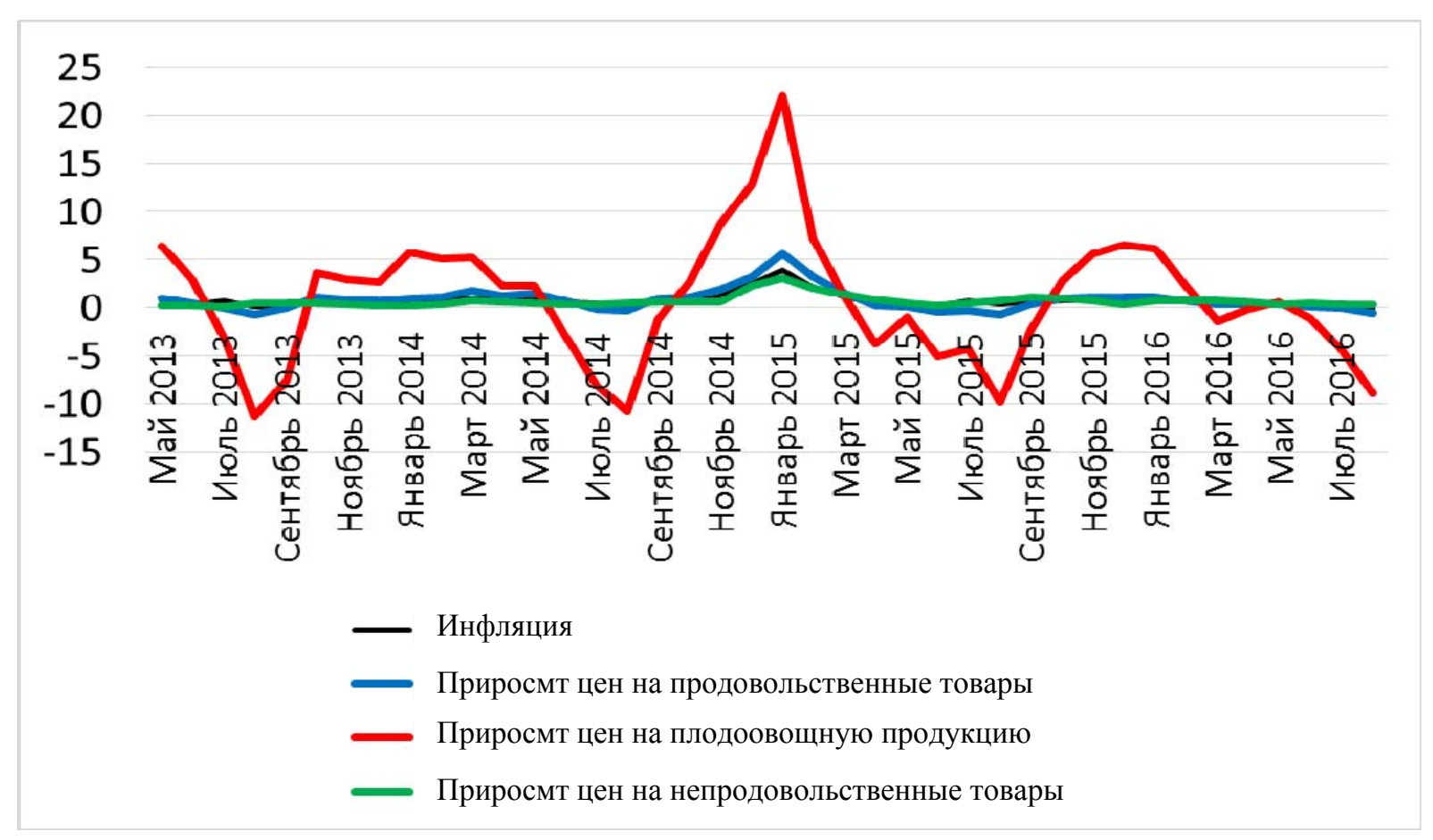

Рис. 6. Темпы прироста цен на продовольственные товары и инфляции в 2013-2015 гг. (\% к предыдущему месяцу) [ http://www.cbr.ru/statistics/infl/Infl_01072015.pdf]

Поскольку в структуре потребительской корзины наиболее затратной статьёй являются продовольственные товары, рассмотрим сначала динамику цен на них, а затем на непродовольственные товары.

Прирост цен на продовольственные товары показан на рис. 6. Цены на продовольственные товары стремительно поползли вверх уже осенью 2014 г., достигнув пика к 2015 г. Они внесли наибольший вклад в увеличение инфляции, что видно на рис. 6. Прирост цен на непродовольственные товары даже отставал от средних темпов инфляции [http://www.cbr.ru/statistics/infl/Infl_01072015.pdf]. Все это вызвало обострение социально-экономических проблем в стране. В результате уровень бедности в 1-2 кварталах 2016 года превысил уровень бедности во время кризиса 2008-2009 гг. [6, c. 19]

\section{2. Последствия антисанкций для Запада}

Последствия российского эмбарго сказались сразу, поскольку запрет на ввоз мяса, молочной продукции и рыбы, овощей и фруктов не мог не отразиться на динамике цен. В 2013 г. почти 40 \% ввезённой в Россию сельскохозяйственной продукции было произведено в странах Евросоюза, и около 4 \% - в США [4]. Суммарная стоимость подпадающих под первую и вторую волны эмбарго товаров составляла на 2013 год около 10 млрд дол. в год. Однако, как ни странно, серьезных последствий для экономики большинства стран Евросоюза российское эмбарго не имело. Это связано прежде всего с тем, что для многих стран экспорт сельскохозяйственной продукции в Россию был относительно невелик. Больше всего должны были пострадать страны, для которых Россия была основным рынком сбыта того или иного запрещенного в рамках эмбарго товара. Таких стран было немного. Это прежде всего Исландия (поставлявшая в 2013 г. $31 \%$ экспорта мороженой рыбы), Финляндия (экспортировавшая 29 \% мяса птицы, $32 \%$ рыбы и 77 \% сыров), Литва (41 \% экспорта свинины и 50 \% экспорта сыров), Эс- 
Нуреев Р.М. Экономические санкции против России и российские антисанкции: издержки и выгоды конфронтации

тония (46 \% экспорта рыбы, 37 \% экспорта сыров), Латвия (34 \% экспорта сыров) и Польша (55 \% экспорта яблок) [2].

На незначительные последствия эмбарго указывает тот факт, что Евросоюз выделил на ликвидацию его последствий небольшую сумму, из которой значительная часть оказалась невостребованной (из 125 млн евро, выделенных Евросоюзом на компенсацию фермерам, пострадавшим от российского эмбарго, оказались востребованы лишь около 37 млн) [2].

\section{3. Исторические судьбы санкций}

Возможны два прогноза ближайшего развития событий с точки зрения рядового потребителя: пессимистический и оптимистический.

Предпосылками для пессимистического прогноза развития является дальнейшее усиление экономических санкций и продолжение падения цен на нефть. В этом случае произойдет углубление экономической изоляции России от мирового сообщества. Санкции могут вызвать приостановку работы системы Visa и MasterCard в России, отключение российских банков от системы SWIFT и т. д. Россия будет вынуждена начать работы по созданию альтернативной системы международных расчетов. И хотя работы в этом направлении уже ведутся, трудно ожидать в ближайшее время ощутимых результатов. В этих условиях Россия будет искать союзников в лице стран БРИКС и, прежде всего, Китае. Это объективно создаст дальнейшие предпосылки к переходу от однополярного мира к многополярному. Любые шаги в этом направлении могут привести к последствиям, о которых многие участники экономического конфликта в краткосрочном периоде даже не догадываются.

Предпосылками для оптимистического прогноза развития являются рост цен на нефть и ослабление экономических санкций. Это приведет к укреплению российского рубля, что создаст большие возможности для увеличения импорта, поскольку сделает его более дешевым. Фактически это будет означать дальнейшее ослабление связей с Западной Европой, и усиление торговли со странами Азии и Латинской Америки. Ослабление экономических санкций позволит восстановить связи с Западной Европой, и тогда произойдет сдвиг с Востока на Запад, поскольку доля западноевропейских товаров увеличится в российском импорте. Это позволит диверсифицировать товарные потоки и выбирать в качестве партнеров те страны, которые предоставляют режим наибольшего благоприятствования для России. Однако даже этот оптимистический прогноз имеет как свои плюсы, так и минусы, поскольку в этом случае усилится конкуренция импортных товаров с отечественными. В этом случае российским производителям придется работать в условиях международной конкуренции. К сожалению, не все из них будут к этому готовы.

\section{Литература}

1. Доклад МВФ по стране № 15 /211. РОССИЙСКАЯ ФЕДЕРАЦИЯ. МВФ (Август 2015). http://www.imf.org/external/russian/pubs/ft/scr/2015/ cr15211r.pdf

2. Продовольственное эмбарго: итоги 2015 года. Аналитический доклад Управления по конкурентной политике, Аналитического центра при Правительстве Российской Федерации. Апрель 2016 года.

3. ЦБРФhttp://www.cbr.ru/DKP/print.aspx?file=standart_system/rates_table_14. htm\&pid=dkp\&sid=ITM_49976

4. Russia Bans Key U.S. Agricultural Exports https://www.fas.usda.

gov/data/russia-bans-key-us-agricultural-exports 
Нуреев Р.М. Экономические санкции против России и российские антисанкции: издержки и выгоды конфронтации

5. World Bank Russia Economic Report. - 2016. - № 35.

6. World Bank Russia Economic Report. - 2016. - № 36.

7. Federal Open Market Committee (2014). Federal Reserve issues FOMC statement. $\begin{array}{llllll}\text { October } & 29 & \text { Available at: http://www.federalreserve.gov }\end{array}$ /newsevents/press/monetary/20141029a.htm.

8. Hodgson G.M. On Fuzzy Frontiers and Fragmented Foundations: Some Reflections on the Original and New Institutional Economics // Journal of Institutional Economics. 2014. - Vol. 10, Special issue 4. - P. 591-611. Available at: http://uhra.herts.ac.uk/bitstream/handle/2299/14771/906911.pdf?sequence=2.

9. Khalil E. Organizations versus Institutions // Journal of Institutional and Theoretical Economics. - 1995. - Vol. 151, № 3. - P. 445-660.

10. Бычков А.А., Подлинных Д.А. Банковский сектор России под влиянием кризиса 2014-2015 годов // Молодой ученый. - 2015. - № 90. - С. 548-551.

11. Загашвили В. Западные санкции и российская экономика // Мировая экономика и международные отношения. - 2015. - № 11. - С. 67-77.

12. Кокошкин A.A. и др. Мировая политика: теория, методология, прикладной анализ. (http://www.obraforum.ru/Mirovaja_politika/chapter11.htm - Дата обращения: 21.11.2016).

13. Ложникова А.В., Розмаинский И.В., Развадовская Ю.В. Техника как национальное богатство России: институциональные аспекты, «статистические иллюзии» и проблемы прогнозирования // Журнал институциональных исследований. - 2015. - Т. 7, № 4. - С. $60-86$.

14. Мельников B.B. Проблема оппортунизма в государственных закупках // Journal of Institutional Studies. - 2013. - T. 5, № 3. - C. 114-124.

15. Нуреев Р.М., Петраков П.К. Рядовой потребитель: бремя экономических санкций против России // Вопросы регулирования экономики. 2015. - Т. 6. - № 3.

16. Нуреев Р.М., Петраков П.К. Экономические санкции против России: ожидания и реальность // Мир новой экономики. - 2016. - № 3.

17. Нуреев Р.М., Латов Ю.В. Россия и Европа: эффект колеи (опыт институционального анализа истории экономического развития). - Калининград: РГУ им. И. Канта, 2009.

18. Погосов И.А. Факторы долгосрочного экономического роста: научнотехнический прогресс и капиталоемкость производства // Проблемы прогнозирования. -2015 . - № 5. - C. 11-24.

19. Ханин Г.И. Современная российская буржуазия (опыт экономического эскиза) // Terra Economicus. - 2013. - № 1. - С. 9-28. Доступно на: http://te.sfedu.ru/evjur/data/2013/journal11_1_1.pdf.

20. Ханин Г.И., Фомин Д.А. Об альтернативных оценках экономического развития бывших республик СССР, стран Восточной Европы и Китая // Вопросы статистики. - 2014. - № 7. - С. 64-79.

Поступила в редакцию 5 июля 2017 г. 
UDC 338.14

DOI: $10.21779 / 2500-1930-2017-32-3-94-102$

\section{Economic sanctions against Russia and Russian anti-sanctions: costs and benefits of con- frontation}

\section{R.M. Nureev}

Financial University under the Government of the Russian Federation; Russia, 125468, Moscow, Leningradskiy, 49; nureev50@gmail.com

The main purpose of the article is to identify the costs and benefits of economic sanctions imposed by USA and EU against Russia and Russian retaliatory sanctions. They were imposed against Russian companies operating in the oil and gas industries, Finance and banking, the military-industrial complex. In response to the economic sanctions Russia imposed an embargo, which has resulted in a ban on the import of meat, fish, dairy products on the territory of the Russian Federation.

This estimates the cost of sanctions for the West and what damage they have caused to Russia, on the one hand, and the Russian counter-sanctions on the other.

The two possible forecasts for the nearest developments from the point of view of the ordinary consumer are considered: pessimistic and optimistic. The basis for a pessimistic forecast is the further strengthening of economic sanctions and the continued fall in oil prices. In this situation, the deepening economic isolation of Russia from the world community

The basis for an optimistic forecast are the increase in oil prices and easing of economic sanctions. This will lead to the strengthening of the Russian ruble, which will create great opportunities for the increase in imports, as this will make them cheaper.

Keywords: western economic sanctions, Russian anti-sanctions, the analysis «costbenefit».

Received 5 July, 2017 